\begin{tabular}{|c|c|}
\hline 論 文 & 極值統計的手法による鋼板および亜鉛系 \\
\hline
\end{tabular}

\author{
佐藤広士* \\ 池田貢基*2 ·岩井正敏*3 ·堺 裕彦*3 · 野村伸吾*3
}

\title{
Analysis of Perforation Corrosion of Cold Rolled and Galvanized Steel Sheets by Extreme-value Statistics
}

Hiroshi Satoh, Kazutoshi Shimogori, Hidetoshi Nishimoto, Kenji Miki, Kouki Ikeda, Masatoshi Iwai, Hirohiko Sakai and Shingo Nomura

\section{Synopsis :}

The perforation corrosion of steel and galvanized steels due to the cyclic corrosion tests $\left(\mathrm{ClC}^{\prime} \mathrm{T}\right)$ has been analyzed by the extreme-value statistics.

The plots of the maximum values of perforation corrosion depth and the cumulative probability gave straight lines and they were fitted to the Gumbel(Doubly exponential probability) distribution.

The decrease of the slope of these lines with CCT time suggested that uniform corrosion occurred in an early stage of CCT but it changed to uneven corrosion with CCTT time.

The period of the uniform corrosion corresponds to the incubation time, $t_{i}$ of perforation corrosion and $t_{i}$ of the steel was extended proportionately with zinc coating weight.

The perforation corrosion rate of $\mathrm{Zn}-\mathrm{Ni}$ alloy electroplated steel after $t_{i}$ was lower than those of other materials. This phenomenon seems to be attributable to formation of a protective corrosion product of $\mathrm{ZnCl}_{2} \cdot 4 \mathrm{Zn}(\mathrm{OH})_{2}$ and a good adhesion of the product to the steel.

\section{1. 緒}

\section{言}

自動車車体用鋼板の腐食要因と形態については，すで に多くの解説が報告されておりり文) てはスキャブュロージョンや系錆，内面腐食としては全 面腐食，すきま腐食，穴あき腐食などが問題となつてい る.これらの腐食のら七，塗料のつきまわりにくい部分 たと壳ばドア袋構造部，フードヘミング部などで発生し やすい公あき腐食は，車体軽量化を図るための鋼板の薄 肉化やユーザの自動車保有期間の延長などの䞨勢を考慮 すると最も重要な腐食形態の一つにあげられる。

公女き腐食の直接原因は, 車体袋構造部に塩分や水が 付着あるいは充満することにあり，この現象を再現する ための促進試験としては塩水噴霧試験 (Salt Spray Test: SST) より SST に乾燥一湿潤工程が付加された複合腐 食試験 (Cyclic Corrosion Test : CCT) の方が適して いることが知られている4)5)。た試験片についても単 一板試験片を用いた研究もあるが ${ }^{6)} ， 2$ 枚の板を命わせ
構造にしてすきまを形成させた試験片の方が先車の分あ き腐食をよく再現できるとの報告もある778).

分あき腐食举動は試験片材質の相違により顕著に異な ることも明らかにされている。すなわも, 鋼板について は低 $\mathrm{Mn}$ 連続焼鈍材 ${ }^{8)}$ や $\mathrm{P}$ 添加鋼9)の响穴あき腐食性が すぐれており，鋼板への $\mathrm{Zn}$ 系めつき6778)10)や $\mathrm{Zn}$ 系 有機皮膜の涂布 ${ }^{11)}$ は柿分あき性を大幅に改善するとされ ている.

これらの研究は材料閒の耐分あき腐食性の相石比較や 迅速評価法の開発などに筫献しているが，今後よりいら そう耐公あき腐食性のすぐれためつき鋼板を開発してい くためには, 分あき腐食現象のより詳細な解析が必要と 思われる.この解析の一手段として近年: $\mathrm{Al}$ の孔食やス テンレス鋼の㐫力腐食割れ現象の解析手法として注目さ れている確影統計論的解析が有效であると考えられる.

このよらな観点から，本報では鋼板ならびに各種 $\mathrm{Zn}$ 系めつき鋼板の CCT を行い，最大公あき腐食深さを極 值解析することにより穴あき腐食の進行過程および穴あ

昭和 61 年: 4 月本会講演大会にて発表 昭和 60 年: 10 月 14 日受付 (Received Oct. 14，1985)

* (株) 神户製鋼所材料研究所工博 (Materials Research Laboratory, Kobe Steel, Ltd., 1-3-18

Wakinohama-cho Chuo-ku Kobe 651)

*2 (株) 神户製鋼所材料研究所 (Materials Research Laboratory, Kobe Steel, Ltd.)

*3 (侏) 神厂製鋼所加古川製鉄所 (Kakogawa Works, Kobe Steel, Ltd.) 
き腐食抑制における Zn 系めつき層の役割について考察 を加えた。

\section{2. 実 験 方 法}

\section{$2 \cdot 1$ 試験片}

供試材としては Table 1 に示す 6 種類の材料を用い た.すなわち, 冷延鋼板 (COLD) としては板厚 0.8 $\mathrm{mm}$ のキルド鋼板で連続焼鈍を施した市販級材を用い た. 電気 $\mathrm{Zn}$ めつき鋼板 (EG) は目付量を 40,80 お よび $100 \mathrm{~g} / \mathrm{m}^{2}$ と変化させた市販級材であり，めつき原 板は上記と同様の鋼板である.（以下同様）合金化溶融 $\mathrm{Zn}$ めつき鋼板 (CGA) は目付量 $45 \mathrm{~g} / \mathrm{m}^{2}$ のものを用 いた. 電気 $\mathrm{Zn}-\mathrm{Ni}$ 合金めつき鋼板 $(\mathrm{Zn}-\mathrm{Ni})$ は $\mathrm{Ni}$ 含 有量 $12 \%$ の市販級材である.

これらの供試材を Fig. 1 に示すように $70 \times 150 \mathrm{~mm}$ の大きさに切り出し, 脱脂, 水洗, 乾燥後裏面および周 囲を有機絶縁テープで被覆したものを CCT に供した.

電気化学的特性の測定用としては上記試験片の CCT 後のものを横方向に幅 $20 \mathrm{~mm}$ で切断し, 有効表面積 10

Table 1. Materials tested and their coating weight.

\begin{tabular}{c|l|l|c}
\hline No & Mark & \multicolumn{1}{|c|}{ Material } & Coating weight $\left(\mathrm{g} / \mathrm{m}^{2}\right)$ \\
\hline $\mathrm{l}^{*}$ & COLD & Cold rolled steel & - \\
\hline 2 & EG40 & Electrogalvanizing & 40 \\
\hline 3 & EG80 & ibid & 80 \\
\hline 4 & EG100 & ibid & 100 \\
\hline 5 & CGA45 & Galvanealing & 45 \\
\hline 6 & Zn-Ni & Zn-12\% Ni electroplating & 30 \\
\hline
\end{tabular}
* Chemical composition of the steel is as follows; C: 0.06 ,
Si: 0. 02, Mn: 0.21, P: 0.008, S: 0.010, Al: 0.066, N: 0.006 and Fe: Bal. (wt\%)

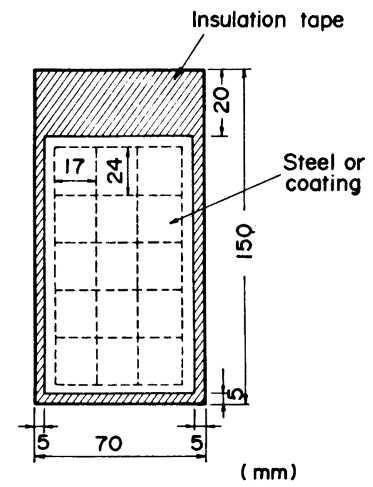

$\left(\begin{array}{l}\text { shows the area for measurement of } \\ \text { corrosion depth. }\end{array}\right)$

Fig. 1. Dimension of the specimen for CGT ( $\mathrm{mm})$.
Table 2. Gyclic corrosion test (GCT).

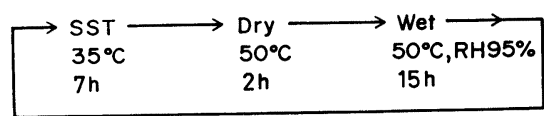

$\times 10 \mathrm{~mm}$ と端子接続部を除いて有機絶縁テープで被覆 したものを使用した.

\section{$2 \cdot 2$ CGT}

穴あき腐食を再現するには，SST のみでなく乾燥 過 程を組みこんだ CGT を採用すべきとの知見 ${ }^{10) 12) を む と ~}$ に, Table 2 に示すサイクルの CCT を行つた. SST には, $\mathrm{pH}$ を.5〜7.2 に調整した $5 \% \mathrm{NaCl}$ 溶液を用 いた.

所定のサイクル後試験片の絶縁テープを除去したの ち， $70^{\circ} \mathrm{C}$ の $10 \%$ クエン酸アンモニウム溶液を用いて 試験片を除錆処理し，水洗，乾燥した．穴あき腐食深さ は細針を設けたダイヤルゲージを用いて測定した.この 時の測定精度は $\pm 5 / 1000 \mathrm{~mm}$ である.

なお一部の試験片については腐食生成物を採取し，そ の組成を同定した.さらに試験片の断面組織を観察し EPMA で腐食生成物の分析を行つた。

\section{$2 \cdot 3$ 最大穴あき腐食深さの極值解析}

同一条件下での CCT に供した同一試験片の数は 3 枚 とした. CCT 後これらの各試験片表面の外周部 $5 \mathrm{~mm}$ 幅を除いて縦 2 列, 横 5 行に分割して $17 \times 24 \mathrm{~mm}$ の区 画を 15 個作成した. (Fig. 1 参照) 各区画内で 5 か所 の腐食深さを測定し, 測定值のヒストグラムを作成し た. 続いて最大值の極值統計処理法に従い各区画中の最 大值を小さなものから順に 45 個 (15 区画 $\times 3$ 枚) 並べ 極值確率紙にプロットした.

\section{4 電気化学的試験}

各試験片の CCT 後における分極曲線を測定した. 試 験溶液は常温の $5 \% \mathrm{NaCl}$ 溶液であり，電位測定用照 合電極には飽和 $\mathrm{KGl}$ 寒天塩橋を介した $\mathrm{Ag} / \mathrm{AgCl}$ 電極 を用いた。また対極には白金めつきチタン板を用い，ポ テンショスタットにより電位走査速度 $50 \mathrm{mV} / \mathrm{min}$ でア ノードおよびカソード分極曲線を測定した.

\section{3. 実 験 結 果}

\section{$3 \cdot 1$ 鋼板の穴あき席食挙動}

CGT を行つた COLD の表面に 15 個の区画を設 け，各区画ごとに 5 か所腐食深さを測定した。同一の試 験片 3 枚についてこの操作を行い，合計 225 個の測定值 を得た. 得られた值の分布をヒストグラムの形で CGT サイクル別に Fig. 2 に示す.

Fig. 2 より穴あき腐食深さは，12 サイクルでは裾野 

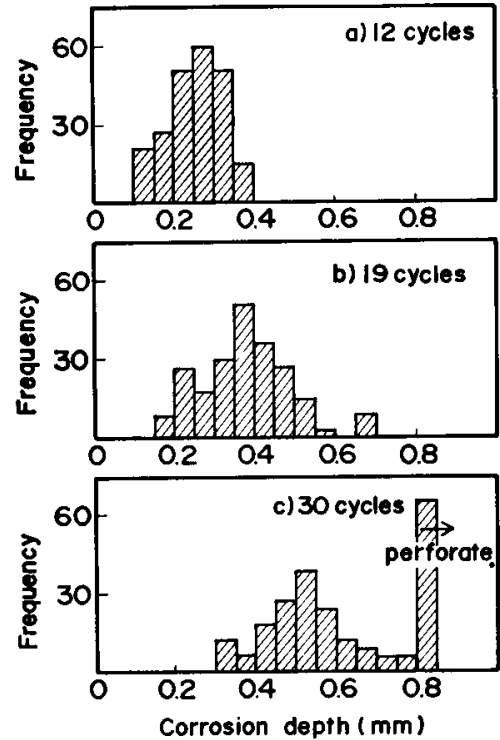

Fig. 2. Histogram of perforation corrosion depth of cold rolled steel after CCT

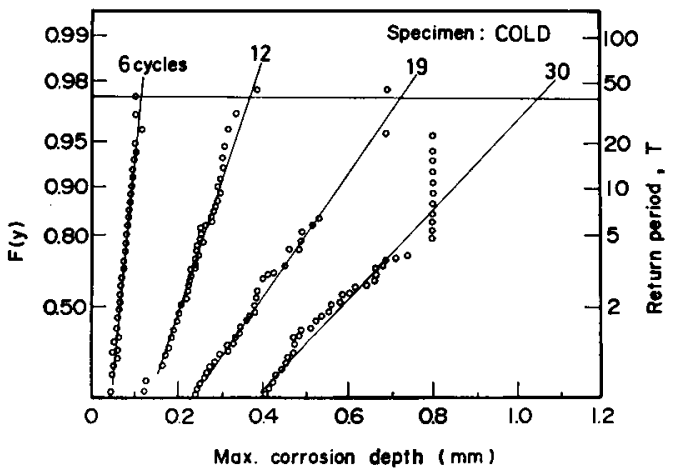

Fig. 3. Doubly exponential probability plots for the maximum perforation corrosion depth of cold rolled steel (COLD).

の狭い正規分布となるが， CGT 時間が 19 サイクルに なるとヒストグラムの右裾野が広がり，正規分布から対 数正規分布へと変化することが分かる.ささらに 30 サイ クルではヒストグラムの中央值が右方向に移行し，貫通 孔を除いた腐食深さは同様に裙野の広がりをもつた対数 正規分布に相当する.このような分布状態は，石油ス卜 レージタンクに用いられた炭素鋼 ${ }^{13)}$ や港湾鋼構造物14な どの腐食深さと同様に指数型の分布と考えられる，した がつて，極値としての最大值の分布である Gumbel 分布 (2 重指数分布) が適応可能として以下の解析を行 つた.
前述の腐食樑さの内，各区画ごとに最大值を求め，后 值解析の手法 ${ }^{15)}$ に従つて 2 重指数確㳯紙にプロットレ た. Fig. 3 に 30サイクルの CCTを行つた COLD についての結果を示す. Fig. 3 よりいずれのCCT サ イクルに招いても比較的良好な值線関係が得られ，CO L D の最大穴あさ腐食深さが 2 重指数分布に適合するこ とが明らかである。しかし各值線を詳細にみると CCT サイクルが長くなるほど直線の傎さが小さくなり，府食 深さの各值が直線から偏倚する度合も大さくなる㑯向に ある. 2 重指数分布の直線の傾きの逆数 $\alpha$ は, 尺度ハラ メータであり標準偏差 $\sigma$ との間に次式が成立する.

$$
\alpha=(\sqrt{6} / \pi) \cdot \sigma
$$

したがつて，尺度パラメータの增加は腐食深さのばら つきが大きくなることを意味し，腐食が程時的に不㚬一 化していくことが推察される.

Photo. 1 は 6〜19 サイクルの CCTを行つた COLD の断面を走查型電子顕徽鏡 (SEM) て観察した 結果である. 6 サイクル（尺度パラメータ $\alpha=0.014$ )で は COLD の表面部は極く浅い食孔が認められるすの の，扣拉さ权均一に腐食されているが 12 サイクル $(\alpha=$

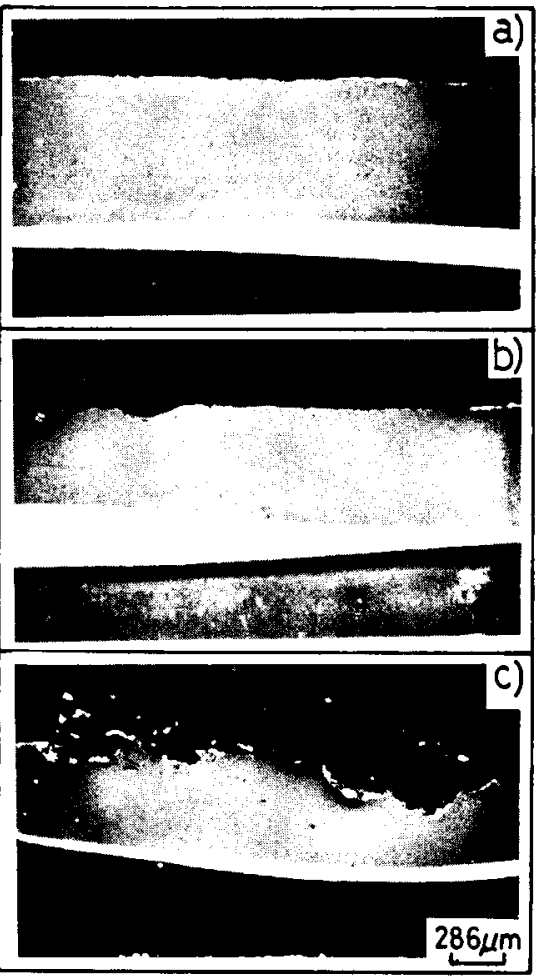

(a) 6 cycles (b) 12 cycles (c) 19 cycles Photo. 1. Cross sectional SEMs of cold rolled steel after CCT. 
0.046) では板厚の均一減少部に隣接して明瞭な食孔が 局部的に観察されるよらになる. そして 19 サイクル $(\alpha=0.104)$ では板厚の減少がいつそう顕著になり表面 も極めて不均一に腐食を受けるようになる.このように 均一腐食から不均一腐食への腐食形態の変化は尺度パ メータがサイクル数とともに大きくなることと対応して いる.

さらに $\mathrm{Zn}$ 系めつき鋼板について腐食後の断面観察を 行つたところ, 尺度パラメータが $0.03 〜 0.04$ になると 不均一腐食が認められ始めることがわかつた。

\section{$3 \cdot 2 \mathrm{Zn}$ 系めつき鋼板の穴あき腐食挙動}

EG 40 についても COLD と同様に穴あさ腐食深さ のヒストグラムを作成した. この結果を Fig. 4 に示す. このヒストグラムは Fig. 2 と同様 CCT サイクルが長 くなるほど中央値が右に移行し, 裾野も広がる傾向を示 したすなわち，EG 40 の穴あき腐食深さの分布も指 数型分布に適合することが判明した. EG 80, EG 100, CGA 45 および Zn-Ni についてもほぼ同様の形状を 示すヒストグラムが得られたので，これら Zn 系めつき 鋼板の最大穴あき腐食深さを 2 重指数分布により解析し た.

Fig. 5〜Fig. 9 にそれぞれ EG 40, EG 80, EG 100, CGA 45 および Zn-Ni の最大穴あき腐食深さの 2 重指 数確率紙へのプロット結果を示す.

まず Fig. 5〜Fig. 7 よりいずれの目付量の EG とも 分布はほぼ直線に近似され 2 重指数分布が適応できるこ
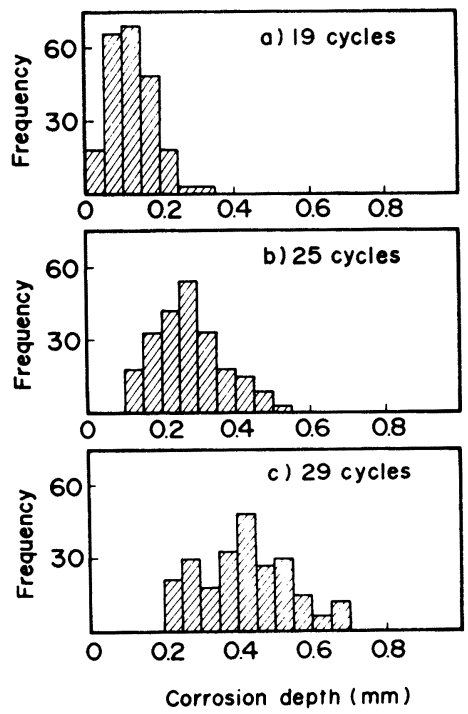

Fig. 4. Histogram of perforation corrosion depth of electrogalvanized steel (EG40) after CGT.

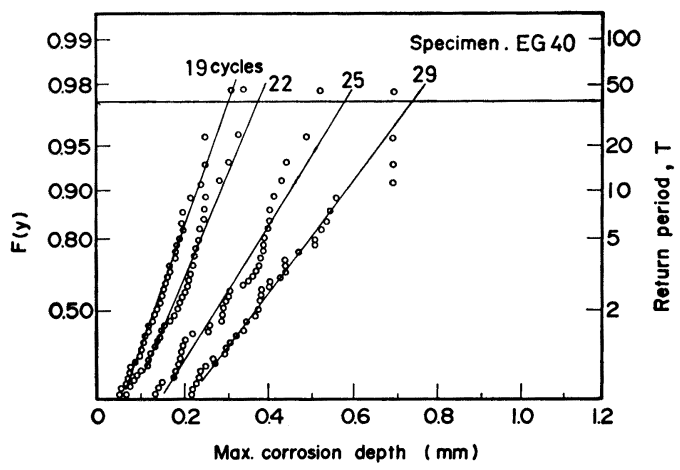

Fig. 5. Doubly exponential probability plots for the maximum perforation corrosion depth of electrogalvanized steel (EG40).

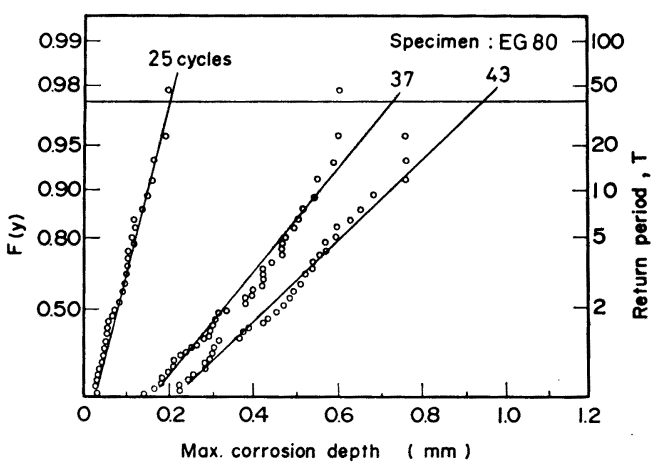

Fig. 6. Doubly exponential probability plots for the maximum perforation corrosion depth of electrogalvanized steel (EG 80).

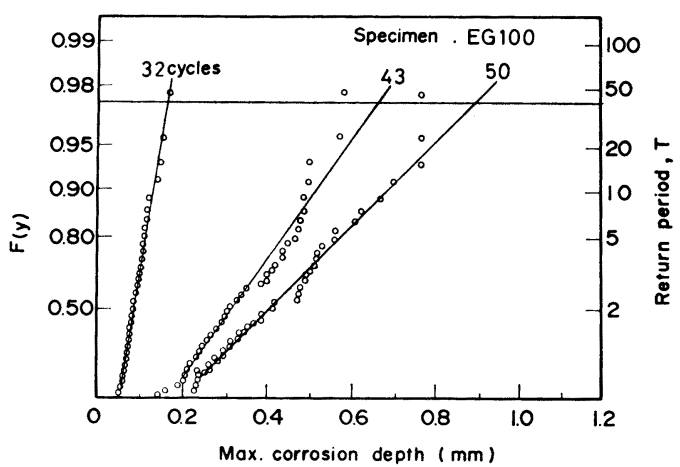

Fig. 7. Doubly exponential probability plots for the maximum perforation corrosion depth of electrogalvanized steel (EG 100).

とを確認した．個々の直線を見ると CCT サイクル数が 長くなるほど傾きの逆数（尺度パラメータ）は大さくな るとともに各データの直線からの偏倚度合も大きくな 


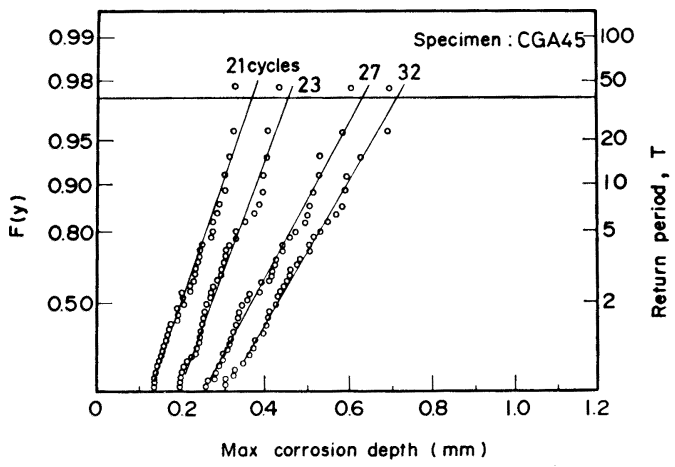

Fig. 8. Doubly exponential probability plots for the maximum perforation corrosion depth of galvanealed steel (CGA45).

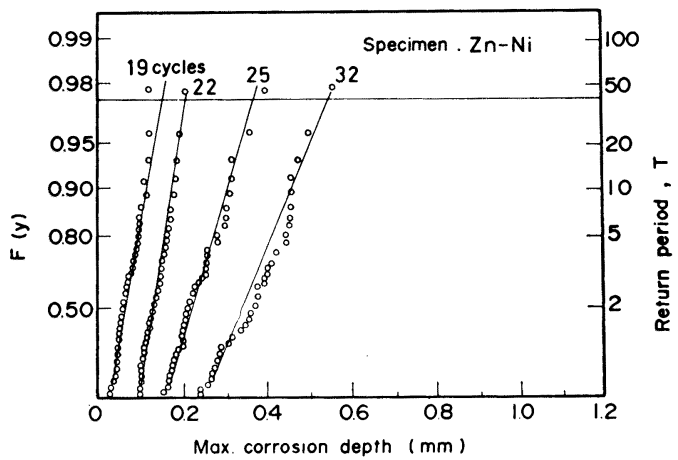

Fig. 9. Doubly exponential probability plots for the maximum perforation corrosion depth of $\mathrm{Zn}$ $\mathrm{Ni}$ electroplated steel $(\mathrm{Zn}-\mathrm{Ni})$.

り，穴あき腐食の初期段階では比較的均一な腐食を受け るが，その後しだいに不均一腐食が起こり表面が粗化す ることがらかがわれる。いうきう，目付量の影響をみる と当然のことながら目付量が 40 から $100 \mathrm{~g} / \mathrm{m}^{2}$ と増え るにしたがつて直線は左方向に移行し穴あき腐食寿命が 改善される。

Fig. 8 に示した CGA 45 については, EG 40 と酷 似した分布を示しており, 目付量が同程度であれば両者 の穴あさ腐食挙動はほぼ同様とみなすことができる.

Fig. 9 の Zn-Ni についても 2 重指数分布は值線と なりその傾きがサイクル数とともに小さくなる傾向はほ かの Zn 系めつき鋼板と同様であるが，各データの直線 への適合度合は 22 サイクルまでは非常に良好であり， しかも直線の傾きの低下もほとんど見られない。すなわ ち，この段階までは $\mathrm{Zn}-\mathrm{Ni}$ は均一な腐食を受けること になる.しかし 25 サイクル以上になると傾きの低下や データのばらつきが見られるよらになり不均一な腐食が 進行し始めることが推察される.

\section{4. 考察}

\section{1 穴あき腐食発生過程と金属めつき屏の役割}

各試験片の 2 重指数確率プロットの直線を外㨉し再㷌 期間 $T$ に打ける試験片全体の最大穴あき腐食深さを推 定した． $T$ は測定に供した 3 枚の試験片の全面積 $S$ (3 枚 $\left.\times 50 \times 115 \mathrm{~mm}=17250 \mathrm{~mm}^{2}\right)$ と 1 枚の試験片に設け た単位区画の面積 $s\left(17 \times 24 \mathrm{~mm}=408 \mathrm{~mm}^{2}\right)$ とで次のよ うに決定される。

$$
T=S / s=42.3
$$

各試験片ごとに得られた最大穴あき腐食深さの推定 值を CCT サイクル数との関係でプロットした結果を Fig. 10 に示す。この図より直線を腐食深さゼ口の点ま で外挿するといずれの試験片ともある一定期間後に穴あ き腐食が進行することがわかる．今この期間を $t_{i}$ とし， Fig. 3 および Fig. 5〜Fig. 9 で示した值線の傾きの逆 数すなわち尺度パラメータのサイクル数による変化をあ わせて考虑すると，穴あき腐食は潜伏期間 $t_{i}$ 後に進行 し，その後 4〜5 サイクルは均一な腐食となるがすぐ 不均一腐食へと変化していくものと思われる.

鋼板の不均一腐食は, 給排水用鋼管16) や蒸気配管 ${ }^{17)}$ で の事故例に見られるよらに鉄錆の厚さや組成に影響され ることが知られている.

本試験において鋼板表面に生成した錆は $\mathrm{Fe}_{3} \mathrm{O}_{4}$ およ び $\alpha, \beta, \gamma-\mathrm{FeOOH}$ を主成分とするものであり，サイ クル数が増えるにしたがつて $\mathrm{FeOOH}$ の量が増大する 傾向にあつた。これらの錆の腐食保護性を比較すると $\mathrm{Fe}_{3} \mathrm{O}_{4}$ より $\mathrm{FeOOH}$ の方が劣つていることが確認され ている、それゆえ CCT 初期においては鋼板表面は保護 性のすぐれた $\mathrm{Fe}_{3} \mathrm{O}_{4}$ を主成分とする鉄錆で覆われるが，

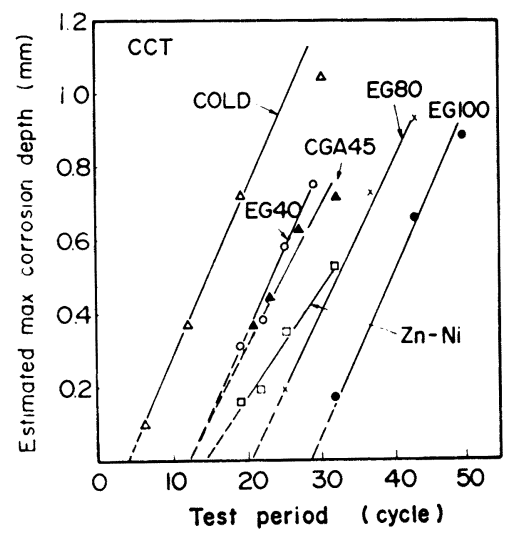

Fig. 10. Relationship between estimated maximum perforation corrosion depth of cold rolled steel and galvanized steels and CGT period. 
錆層が厚く成長すると $\mathrm{FeOOH}$ の增大などにともなら 組成や性状の不均一性が生じ, 外部から酸素の補給され やすい所とされにくい所とが存在するようになり，いわ ゆる酸素濃淡電池が形成されるものと推測される.この ような場合には酸素欠乏部がアノードとなり下記の反応 が進行する.

$$
\begin{aligned}
& \mathrm{Fe} \rightarrow \mathrm{Fe}^{2+}+2 e \\
& \mathrm{Fe}^{2+}+\mathrm{H}_{2} \mathrm{O} \rightarrow \mathrm{FeOH}^{+}+\mathrm{H}^{+}
\end{aligned}
$$

(4) 式の反応の到達平衡 $\mathrm{pH}$ は 4.7518) とされており

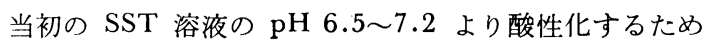
局部的な鋼板の腐食速度が増大するものと思われる.ち なみに CCT 19 サイクル直後の鋼板表面に付着した湿 潤錆層の $\mathrm{pH}$ を実測した結果 4〜5 程度の值であり，上 記推定の妥当性が確認された.

つぎに Fig. 10 における $\mathrm{Zn}$ 系めつき鋼板の $t_{i}$ に 注目すると, Fig. 11 に示すよらにめつき目付量が増え るほど $t_{i}$ は長くなる。 しか子 $t_{i}$ は $\mathrm{EG}, \mathrm{CGA}$ およ び $\mathrm{Zn}-\mathrm{Ni}$ のめつき種類に多少依存するが, 目付量によ りほぼ一義的に決定されると考えられる.

安谷屋ら 6) 女鋼板の穴あき腐食が $t_{i}$ を持せ， $\mathrm{Zn}$ 系 めつきの付与により $t_{i}$ が長くなることを報告している が， $t_{i}$ は同じ目付量のめつき鋼板でも $\mathrm{Zn}$ 系めつきの 組成すなわち $\mathrm{Fe}$ や $\mathrm{Ni}$ の含有量により大きく変化する としており, 本研究結果とは異なつた結果を得ている. この差異についての詳細原因は不明であるが，試験片表 面への電着塗装やクロスカットの有無, 腐食環境の相違 などに起因しているものと思われる.

いずれにしろ, Fig. 10 に示した COLD の $t_{i}$ が Zn 系めつきの付与により長くなるのはめつき層が素地鋼板 より卑な電位を有するため鋼板に対して犠牲防食効果を 発揮することに起因している. ちなみに 10 サイクル後 の EG 40, CGA 45 および $\mathrm{Zn}-\mathrm{Ni}$ の常温 $5 \% \mathrm{NaCl}$ 溶

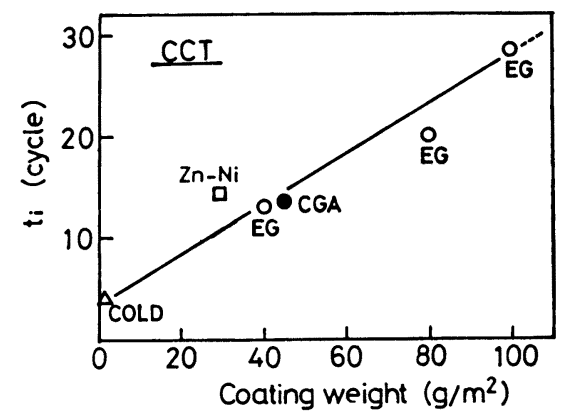

Fig. 11. Effect of coating weight on the initiation period $t_{i}$ of perforation corrosion for cold rolled steel and galvanized steels.
液中における自然電位はいずれも $-0.60 〜-0.65 \mathrm{~V}$ (vs $\mathrm{Ag} / \mathrm{AgCl})$ の範囲にあり, 鋼板の自然電位 $-0.55 \sim-$ $0.58 \mathrm{~V}$ より卑な值を示した. また，めつき目付量を多 くすることは素地鋼板の露出時間を遅くすることにより $t_{i}$ を長くする役割を果しているものと考えられる.

以上のように $t_{i}$ が穴あき腐食開始の潜伏期間である ことを考察したが， $t_{i}$ 以降の穴あき腐食進行過程を示 す直線の傾きについて以下に考察する.

\section{2 穴あき度食進行過程とめつき腐食生成物の役割}

Fig. 10 より COLD, EG 40, EG 80 および EG 100 の直線の傾きはほぼ同等であるが，これらに比べて CGA 45 や特に Zn-Ni の直線の傾きが小さいといら 差異が生じた.この事実は鋼板上への電気純 $\mathrm{Zn}$ めつき はいつたん穴あき腐食が進行し始めるとめつき目付量に 関係なく鋼板とほぼ同じ速度で進行するが，合金化溶融 Zn めつきはわずかに，そして Zn-Ni めつきはかなり 穴あき腐食速度を低減できることを示している.

このことを確認するために， COLD, EG 40, CGA

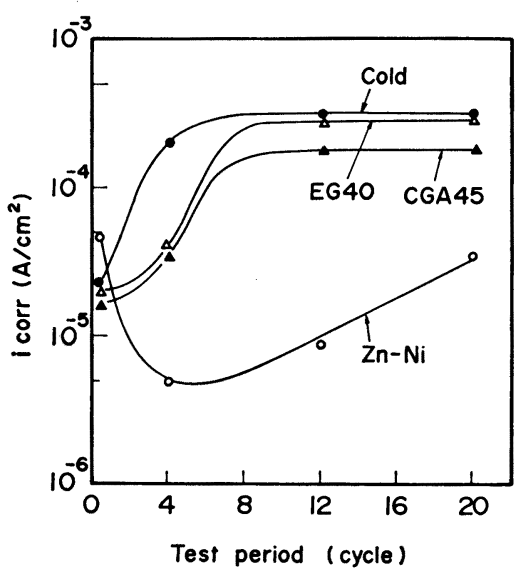

Fig. 12. Change in corrosion current density $i_{\text {corr }}$ of galvanized steels after CCT in a $5 \%$ $\mathrm{NaCl}$ solution at room temperature with CGT period.

Table 3. X-ray peak ratio of $\mathrm{ZnCl}_{2} \cdot 4 \mathrm{Zn}(\mathrm{OH})_{2}$ to $\mathrm{ZnO}$ formed on galvanized steels after CGT.

\begin{tabular}{l|c|c|c|c}
\hline \multirow{2}{*}{ Specimen } & \multirow{2}{*}{$\begin{array}{c}\text { CCT period } \\
\text { (cycle) }\end{array}$} & \multicolumn{2}{|c|}{ X-ray intensity (cps) } & \multirow{2}{*}{$\mathrm{C}=\frac{\mathrm{A}}{\mathrm{B}}$} \\
\cline { 3 - 4 } $\mathrm{EG40}$ & 4 & $\mathrm{ZnCl}_{2} \cdot 4 \mathrm{Zn}(\mathrm{OH})_{2}$ & (B) $\mathrm{ZnO}$ & \\
\hline \multirow{2}{*}{ CGA45 } & 20 & 3400 & 4500 & 0.53 \\
& 4 & 3000 & 4650 & 0.71 \\
\hline \multirow{2}{*}{$\mathrm{Zn}-\mathrm{Ni}$} & 20 & 3860 & 2340 & 1.65 \\
\hline & 4 & 4650 & 2100 & 2.21 \\
& 20 & 5150 & 2240 & 2.30 \\
\hline
\end{tabular}




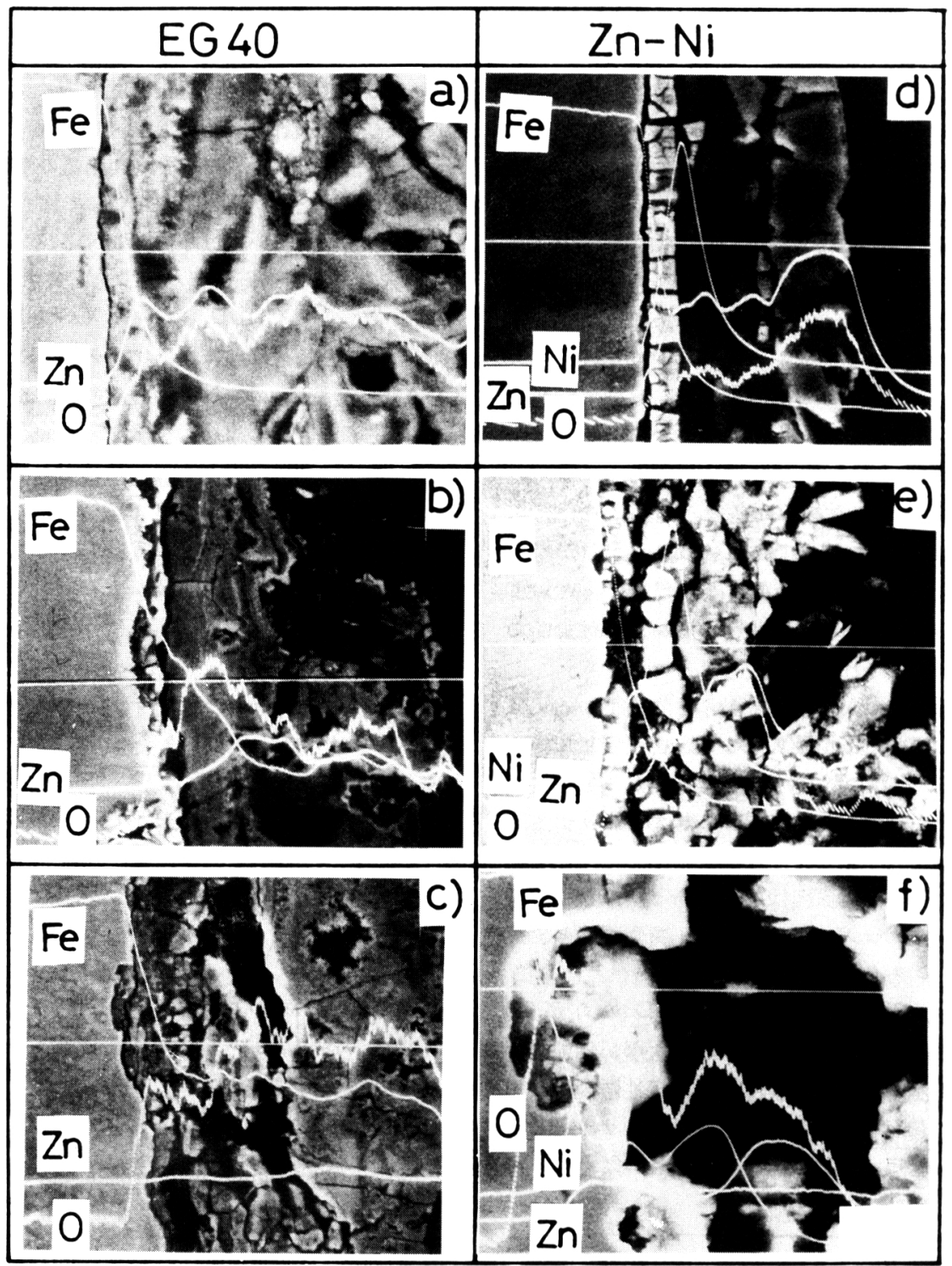

(a) \& (d) : 7 cycles, (b) \& (c) : 19 cycles, (e) \& (f) : 32 cycles

Photo. 2. Cross sectional SEMs of electrogalvanized steel (EG40) and $\mathrm{Zn}-\mathrm{Ni}$ electroplated steel after CCT.

45 および Zn-Ni について最高 20 サイクルの CCT を行つた後常温の $5 \% \mathrm{NaCl}$ 溶液中にてアノードおよ びカソード分極曲線を測定し，両者から PEARSON の方 法により腐食電流密度 $i_{\text {corr }}$ を求めた。 $i_{\text {corr }}$ と CGTサ イクル数との関係を Fig. 12 に示す. この図から CO LD, EG 40 および CGA 45 は 12 サイクル後一定な $i_{\text {corr }}$ を示すが CGA 45 は COLD や EG 40 に比べわ
ずかにその值が小さくなるまた $\mathrm{Zn}-\mathrm{Ni} の i_{\text {corr }}$ の経 時変化はほかの試験片とは異なつた傾向をとり 4 サイク ルで最少值を示し、サイクル数が増すほど $i_{\text {corr }}$ は増大 した.しかし 20 サイクルにおいても Zn-Ni の $i_{\text {corr }}$ COLD，EG 40 および CGA 45 の約 1/10 であり, $\mathrm{Zn}-\mathrm{Ni}$ 上に生成する腐食生成物が極めて 良好な腐食保 護能力を有していることがらかがわれる. 
そこでこれら試験片表面に生成した腐食生成物をX線 回折により解析した．X線回折パターンからは多くのピ ークが検出されたが，一般に $\mathrm{Zn}$ 系めつき鋼板では $\mathrm{ZnO}$ を主成分とする腐食生成物に比べ $\mathrm{ZnCl}_{2} \cdot 4 \mathrm{Zn}$ $(\mathrm{OH})_{2}$ を主成分とするものが生成した際に耐食性がす ぐれると言われている19)。そこで両物質のX線カウント 数を測定しその比を求めた. この結果を Table 3 に示 す. Table 3 より $\mathrm{ZnCl}_{2} \cdot 4 \mathrm{Zn}(\mathrm{OH})_{2} / \mathrm{ZnO}$ のX線ピー ク比 $C$ は, EG 40 が最も小さく, ついで CGA 45 と なり $\mathrm{Zn}-\mathrm{Ni} の C$ は非常に大きくなつた。この結果は OKADA ら ${ }^{20}$ による $\mathrm{Zn}$ 中の $\mathrm{Ni}$ が $\mathrm{Zn}(\mathrm{OH})_{2}$ の $\mathrm{ZnO}$ への変質を抑制するとの報告に一致している.

$\mathrm{ZnCl}_{2} \cdot 4 \mathrm{Zn}(\mathrm{OH})_{2}$ の防食機構としては, この電気伝 導性が劣るため表面の電気化学反応を抑制することに起 因していると説明されているが，これだけでは Zn-Ni の穴あき腐食速度が注かのめつき鋼板より小さいことを 十分に説明できない。

そこで CCT を行つた $\mathrm{Zn}-\mathrm{Ni}$ の断面を SEM およ び EPMA で観察し腐食生成物の生成状況と穴あき腐食 状況を観察した. その結果を Photo. 2 に示す. この写 真には此較材として EG 40 の結果もあわせて示した. まず EG 40 についてみると（a）の7サイクルでは $\mathrm{Zn}$ めつきの上に $\mathrm{Zn}$ の腐食生成物が密に堆積して素地 鋼板の腐食状況も均一である。しかし19 サイクルでは （b）に示すよらに腐食生成物が鋼板に密着している部 分では鋼板の腐食状況は比較的均一であるが，（c）のよ らに腐食生成物が鋼板から剝離した所に鋼板の局部的侵

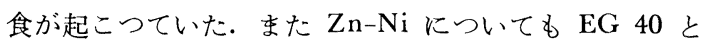
同様の傾向であり（d）の7サイクルでは均一腐食であ るが 32 サイクルになると（e）と（f）から明らかな よらに腐食生成物の鋼板への密着または剥離により腐食 状況が均一腐食と不均一腐食に変化する.

以上のよ5に穴あき腐食は腐食生成物の組成のほかに 鋼板への密着度にも大きく依存していると思われる．密 着性を支配する因子としては, 腐食生成物組 成の均一 性，素地に対する保護性などがあげられるが，その詳細 については未検討である. しかし CCT 後の除錆処理時 に Zn-Ni 上に生成した腐食生成物は EG や CGA に 比べ剝離しにくいといら現象が観察されたことから， $\mathrm{Zn}-\mathrm{Ni}$ 上に生成した腐食生成物は素地への密着性がす ぐれていることも穴あき腐食速度が小さいことの一因で あると考えられる。

\section{5. 結 言}

鋼板および $\mathrm{Zn}$ 系めつき鋼板の CCT を行い穴あき
腐食挙動を最大穴あき腐食深さの極値解析により解析し た．得られた結果を要約すると以下のようになる。

（1）鋼板および $\mathrm{Zn}$ 系めつき鋼板の最大穴あき腐食 深さは 2 重指数分布 (Gumbel 分布) に対応し, その直 線の傾きは CGT サイクル数が増大するほど小さくな る. すなわち, 穴あき腐食深さの分布が大きくなる.

（2）穴あき腐食は CGT 初期には均一腐食が主体で あるが, 経時的に不均一腐食へと変化していく.

（3）穴あき腐食の潜伏期間 $t_{i}$ は $\mathrm{Zn}$ 系めつきの付 与により大幅に長くなる.これはめつきの種類よりむし ろめつき目付量に比例するものと考えられる.

(4) $t_{i}$ 後の穴あき腐食速度は COLD，EG ともほ ぼ同等で, CGA がわずかに小さいが $\mathrm{Zn}-\mathrm{Ni}$ はかなり 小さい值を示す.

(5) $\mathrm{Zn}-\mathrm{Ni}$ の小さな穴あき腐食速度は, $\mathrm{ZnCl}_{2}$. $4 \mathrm{Zn}(\mathrm{OH})_{2}$ を主体とする腐食生成物が生成することお よび腐食生成物の素地鋼板への密着性がすぐれているこ とに由来しているものと思われる.

\section{交献}

1) Aktiebolaget Svensk Bilproving: Gars Go Rusty (1973), p. 12

2 ）小西健吉：自動車技術，32(1978), p. 24

3 ) 三吉康彦，門 智：防食技術，28(1979), p. 645

4) 小山 浩：防食技術，30(1982)，p. 34

5 ）黑川重男, 市田敏郎, 本庄徹, 大和康二: 鉄と 鋼, 71 (1985), S 433

6 ) 安谷屋武志, 原 富啓, 涺山勝, 本間俊之, 渡 辺勉: 鉄と鋼, 70(1984), A92

7 ) 吉康彦：実務表面処理，32(1985)，p. 319

8 ) $S$. Kobayashi, $T$. Irie and $H$. Takahashi: Spec. Pub. Soc. Automot. Eng., SP-538 (1983), p. 23

9 ) 高尾研治, 安田顕, 小林繁, 市田敏郎, 入江 敏夫：鉄と鋼, 71 (1985), S 435

10）下郡一利, 三木賢三, 池田貢基, 野村伸吾, 寺田 誠：鉄と鋼, 70 (1984), A 100

11) 尾家義弘, 米野実, 増田一広, 岡 襄二, 新藤 芳雄：鉄と鋼，69(1983), S 404

12）須賀 藉：第 53 回腐食防食シンポジウム資料, 表面処理鋼板の腐食之評価 (1984)

13）主浦周敏：第 41 回腐食防食シンポジウム，22 (1982)

14）伊藤咯, 佐藤栄次, 村田朋美：第 28 回腐食防 食討論会予稿集 (1981)，p. 113

15）たとえば，腐食防食協会編：装置材料の寿命予測 入門 (1984), p. 81 [丸善]

16）石川雄一, 尾崎敏範, 保坂信義, 西田脩: 防食 技術，29(1980)，p. 502

17）松島 䉷, 酒井潤一, 正村克身, 橋瓜修司：第 30 回腐食防食討論会予稿集 (1983)，p. 191

18）小若正倫：日本材料学会腐食防食部門委員会資料 (1980), p. 18

19) P. T. Gilbert: J. Electrochem. Soc., 99 (1952), p. 16

20) $H$. Okada, $K$. Yамamoto and $I$. Ito: Proc. International Congress on Metallic Corrosion (1972), p. 275 